\title{
Multi-scale detection of rate and variance changes in neuronal spike trains
}

\author{
Stefan Albert ${ }^{1 *}$, Michael Messer ${ }^{1}$, Brian Rummell ${ }^{2}$, Torfi Sigurdsson ${ }^{2}$, Gaby Schneider ${ }^{1}$ \\ From 24th Annual Computational Neuroscience Meeting: CNS*2015 \\ Prague, Czech Republic. 18-23 July 2015
}

Neuronal spike trains can show variability with respect to process parameters such as the rate or variability of inter spike intervals. These changes can occur on fast and slow time scales, including also simultaneous and separate changes in different process parameters.

Building up on results of [1] we present a multiple filter technique (MFT) that detects change points in the rate and variance of point processes on multiple time scales simultaneously. In particular, we use a filtered derivative process and its limit behavior under stationarity. The method also extends to higher order moments.

The separate detection of rate and variance changes requires two techniques: First, rate changes need to be detected, irrespective of potential variance changes. To this end, our approach allows the identification of rate changes in point processes with a certain variability in their lifetimes. Second, the identified rate changes need to be considered when analyzing variance changes. We investigate the empirical properties of our asymptotic MFT method in simulations and apply the MFT to spike trains recorded from auditory cortex of behaving mice, illustrating rate and variability dynamics during the task.

\section{Acknowledgements}

This work was supported by the German Federal Ministry of Education and Research (BMBF, Funding number: 01ZX1404B; SA, TS, GS) and by the Priority Program 1665 of the DFG (TS, GS).

\section{Authors' details}

1 Institute of Mathematics, Goethe-University, Frankfurt am Main, Germany.

${ }^{2}$ Institute of Neurophysiology, Goethe-University, Frankfurt am Main, Germany.

Published: 18 December 2015

\footnotetext{
* Correspondence: albert@math.uni-frankfurt.de

${ }^{1}$ Institute of Mathematics, Goethe-University, Frankfurt am Main, Germany

Full list of author information is available at the end of the article
}

\section{Reference}

1. Messer M, Kirchner M, Schiemann J, Roeper J, Neininger R, Schneider G: A multiple filter test for the detection of rate changes in renewal processes with varying variance. Annals of Applied Statistics 2014, 8(4):2027-2067.

doi:10.1186/1471-2202-16-S1-P217

Cite this article as: Albert et al:: Multi-scale detection of rate and variance changes in neuronal spike trains. BMC Neuroscience 201516 (Suppl 1):P217.
Submit your next manuscript to BioMed Central and take full advantage of:

- Convenient online submission

- Thorough peer review

- No space constraints or color figure charges

- Immediate publication on acceptance

- Inclusion in PubMed, CAS, Scopus and Google Scholar

- Research which is freely available for redistribution

Submit your manuscript at www.biomedcentral.com/submit
() Biomed Central
C Biomed Central

(c) 2015 Albert et al. This is an Open Access article distributed under the terms of the Creative Commons Attribution License (http:// c) 2015 Albert et al. This is an Open Access article distributed under the terms of the Creative Commons Attribution License (http://
creativecommons.org/licenses/by/4.0), which permits unrestricted use, distribution, and reproduction in any medium, provided the original work is properly cited. The Creative Commons Public Domain Dedication waiver (http://creativecommons.org/publicdomain/ zero/1.0/) applies to the data made available in this article, unless otherwise stated. 